\title{
DOI https://doi.org/10.36059/978-966-397-241-1-32
}

\author{
Рібцун Ю. В. \\ кандидат педагогічних наук, старший науковий співробітник, \\ старший науковий співробітник відділу логопедї \\ Інститут спеціальної педагогіки і психологї \\ імені Миколи Ярмаченка \\ Національної академії педагогічних наук України \\ м. Київ
}

\section{ЛОГОПСИХОКОМПЕНСАЦИЙНА РОБОТА 3 МОЛОДШИМИ ШКОЛЯРАМИ З ТЯЖКИМИ ПОРУШЕННЯМИ МОВЛЕННЯ}

Аналіз наукової, навчально-методичної психолого-педагогічної, логопедичної та психолінгвістичної літератури підтверджує наявність у дітей із тяжкими порушеннями мовлення (ТПМ), окрім значних відставань у всіх видах мовленнєвої діяльності (слухання, розуміння, говоріння, читання, письмо), своєрідних особливостей у пізнавальному, особистісному розвитку, сенсомоториці, емоційновольовій сфері, соматичної ослабленості. Все вищезазначене в цілому утруднює, а іноді й взагалі унеможливлює опанування учнями навчальних предметів, особливо мовного циклу. Системна продуктивна взаємообумовленість діагностичної та компенсаційної роботи потребує виявлення характеру, глибини та ступеня мовленнєвих розладів, ретельного аналізу усіх компонентів мовленнєвої системи. Це допоможе у створенні сучасних психотехнологій розвитку для ефективної роботи з дітьми, які мають мовленнєві порушення. Міждисциплінарний теоретичний аналіз літературних джерел з проблеми дослідження, урахування нейро- та психолінгвістичного, компетентнісного, диференційованого, дитиноцентричного, діяльнісного та ін. підходів лягли в основу даного розділу, в якому репрезентовано основні напрями логопсихокомпенсаційної роботи з молодшими школярами із ТПМ. Експериментальне впровадження розробленої нами методики логопсихокомпенсаційної роботи зі здобувачами початкової освіти із тяжкими порушеннями мовлення, використання метакогнітивних стратегій пізнавального розвитку молодших школярів підтвердило на практиці свою ефективність і функціональну дієвість. 


\section{Вступ}

Нова українська школа - це сучасний заклад, який дає змогу учням не лише навчатись, а й переносити набуті знання, уміння та навички у повсякденне життя, оволодівати основними компетентностями. Спільними для всіх компетентностей є наскрізні уміння, зокрема читання з розумінням, уміння висловлювати власну думку в усній та писемній формах, критичне та системне мислення, здатність логічно міркувати, творчість, ініціативність, вміння конструктивно керувати емоціями, оцінювати ризики, приймати рішення, розв'язувати проблеми, співпрацювати з іншими людьми [1].

Учні з тяжкими порушеннями мовлення навчаються в загальноосвітніх закладах і мають у повній мірі опановувати типові навчальні програми. Водночас своєрідність психомовленнєвого розвитку дітей зазначеної категорії супроводжується деяким уповільненням мозкової активності, загальних нейродинамічних показників психічної діяльності, що зумовлює певне зниження розумової працездатності, якості запам'ятовування та відтворення навчального матеріалу, наявність доволі швидкої виснажуваності та втомлюваності (Е. Данілавічютє, В. Ільяна, С. Конопляста, І. Мартиненко, 3. Мартинюк, Ю. Рібцун, Є. Соботович, В. Тищенко, Л. Трофименко, Н. Чередніченко та ін.) [2]. Це свідчить про необхідність проведення цілеспрямованої роботи щодо удосконалення універсальних навчальних дій здобувачів початкової освіти із тяжкими порушеннями мовлення.

На засадах психолінгвістичного, нейропсихологічного, командного та діяльнісного підходів, з урахуванням стану сформованості комунікативного та лінгвістичного компонентів мовленнєвої діяльності, особистісних, вікових особливостей школярів означеної категорії, нами розроблені психолінгвістичні дидактичні технології діагностики й подолання мовленнєвих порушень у здобувачів початкової освіти із ТПМ, запропоновано метакогнітивні стратегії пізнавального розвитку учнів. Все вищезазначене сприятиме удосконаленню організації, оновленню змістового наповнення та реалізації провідних завдань спеціальної освіти, підвищенню ефективності комплексного подолання мовленнєвих порушень.

\section{1. Стратегії забезпечення пізнавального розвитку молодших школярів із тяжкими порушеннями мовлення}

Навчання в умовах Нової української школи вимагає від педагогів пошуку та застосування інноваційних освітніх технологій, 
розроблення сучасних стратегій ефективного та якісного опанування учнями різноманітними навичками навчальної діяльності.

Поняття стратегій досить широке і у різних галузях знань має свої дефініції. У педагогіці та психології - це і деякий спосіб набуття, збереження та використання інформації, що слугує для досягнення певних цілей; i закономірності в прийнятті рішень в ході пізнавальної діяльності; і оптимальний вибір сукупності педагогічних дій, спрямованих на успішне досягнення стратегічно значущої педагогічної мети засобом актуалізації потенціалу суб'єктів освітнього процесу, організації їх продуктивної взаємодії та використання необхідних педагогічних ресурсів [3].

Серед освітніх виділяють прямі та непрямі стратегії. Прямими стратегіями вважають такі, які безпосередньо впливають на успішність реалізації педагогічних цілей і характеризують власне педагогічну взаємодію, зміст, форми та способи. Непрямими є такі, котрі опосередковано сприяють успішному досягненню педагогічних цілей і відображають деяку систему умов інтенсифікації освітнього процесу та впливають на його ефективність.

Психічний розвиток сучасних школярів зумовлений станом системи шкільної освіти, при зміні якої якісно та кількісно змінюються і показники розвитку учнів. В умовах Нової української школи основні завдання освіти вже не зводяться до передачі знань у готовому, фіксованому вигляді, а вимагають швидкого i максимально повного орієнтування у постійно змінюваних життєвих обставинах. Презумпція талановитості кожної дитини, цінність дитинства, радість пізнання, розвиток особистості, здоров'я та безпека - ось головні принципи, на яких грунтуються сучасний навчальний процес і відповідні стратегії освіти.

Здобувачі початкової освіти з тяжкими порушеннями мовлення мають певні особливості, що заважають їм в опануванні навичок навчальної діяльності, а саме: слабка активізація мисленнєвої діяльності, низький рівень мовленнєвого розвитку, стану сформованості різних видів уваги та пам'яті. Зокрема, через обмежений лексичний запас, недостатній рівень володіння прийомами смислової обробки тексту учні початкових класів з ТПМ відчувають значні труднощі при переказі прочитаного тексту, адже не можуть переказати прочитане своїми словами, прагнуть повторити текст слово в слово, навіть не змінюючи граматичних або цілісних синтаксичних конструкцій.

Знижений рівень гнучкості та уповільнений темп інтелектуальної діяльності, шаблонність, слабкість синкретичності мислення, 
обмежена усвідомленість своїх розумових дій, недостатня сформованість мисленнєвих операцій абстрагування, узагальнення, аналізу та синтезу (особливо зорового, слухового, аналізу через синтез, аналізу оптико-просторових відношень, синтезу звукографічних елементів), яскраві індивідуально-типологічні особливості (зокрема холеричний тип темпераменту), інерція збудження чи передчасне гальмування, незначна сформованість внутрішнього плану дій призводять до наявності великої кількості помилок при читанні та на письмі.

Все вищеозначене спричинює зниження рівня засвоєння навчального матеріалу, слабке орієнтування на площині сторінки підручника, зошита, альбомного аркуша, недостатнє опанування співвідношення словесних позначень знайомих символів і їх графічної форм (плюс- мінус - дорівнює, більше - менше; крапка - двокрапка - кома, дефіс - тире, знак оклику - знак питання - дужки - лапки), низькорівневе оволодіння лінгвістичними (звук - буква, частина мови - частина слова) і математичними (число - цифра, віднімання - додавання, множення - ділення) поняттями, утруднення у встановленні фонемо-графічних асоціацій, наявність численних персеверацій, контамінацій, елізій на рівні звуко-буквеної, складової та лексико-граматичної структур. Учні із ТПМ зі значними труднощами пропорційно та оптико-просторово правильно відтворюють композицію під час малювання, ліплення та конструювання, засвоюють правила розміщення навчального матеріалу - плутають розташування нот на нотному стані, при списуванні речень чи тексту воно часто починається з останнього елемента, а записування прикладів у стовпчик - знизу вгору. Діти зазначеної категорії не завжди запам'ятовують і використовують алгоритмів записування класної та домашньої робіт, умов та розв'язання прикладів і задач, виконання вправ з фонетичного, фонемо-графічного, складового, морфологічного та синтаксичного аналізу тощо.

В освітньому та корекційно-розвивальному процесі Нової української школи педагоги мають обов'язково враховувати зазначені особливості психомовленнєвої діяльності здобувачів початкової освіти із тяжкими порушеннями мовлення та будувати такі освітні стратегії, які допоможуть учням в опануванні нових способів навчально-пізнавальної діяльності.

Щоб вироблення стратегій освіти дітей із тяжкими порушеннями мовлення відбувалось ефективніше, доречно проаналізувати існуючі найвагоміші теорії взаємозв'язку навчання та розвитку крізь призму психолінгвістичного підходу. 
Жан Піаже (Жан Вільям Фріц Піаже) - швейцарський філософ, психолог, засновник теорії когнітивного розвитку та Женевської школи генетичної психології, вважав, що розвиток йде попереду, відбувається спонтанно, циклічно, за власними законами і не залежить від навчання. Вчений наголошував, що навчання $\epsilon$ зовнішнім процесом, тому лише за умов дозрівання певних функцій доцільно розпочинати засвоєння тієї чи іншої інформації. Можна провести паралель щодо необхідності розуміння педагогом механізмів засвоєння школярами різних видів інформації (візуальної, аудіальної) та тих передумов, без яких це опанування знаннями $\epsilon$ неможливим; усвідомлення того, що особливості мовленнєвого порушення можуть перешкоджати учням навчатись, i відповідно до цього будувати освітні маршрути розвитку дітей.

Ед Торндайк (Едвард Лі Торндайк) - американський психолог і педагог, президент Американської психологічної асоціації, та Джон Уотсон (Джон Бродес Уосон) - американський психолог, засновник біхевіоризму, стверджували, що навчання і $\epsilon$ розвиток. Розвиток дитини зумовлений певними генами свідомості та відбувається шляхом вироблення правильних реакцій на зовнішні стимули (біхевіористське «стимул $\rightarrow$ реакція»). Так само діти з розладами мовлення шляхом багаторазових вправлянь автоматизують навички правильної звуковимови, реагуючи на зоровий (артикуляція - положення губ, язика), акустичний (фонема), кінестетичний (горизонтально розташоване ребро руки, ніби розтягнуті в посмішку губи - звук [c]), руховий (стрибки з відведенням рук назад (коник - комаха) - звук [ч]), сенсорний (смак, нюх) стимули.

Джон Дьюї - американський педагог і філософ в напрямі прагматизму, зазначав, що навчання та розвиток знаходяться у взаємозв'язку. Навчання спирається на актуальний розвиток, випереджає та стимулює його. Опанування новими знаннями відбувається за наступним алгоритмом: відчуття труднощів $\rightarrow$ формулювання проблеми $\rightarrow$ перевірка гіпотез її вирішення $\rightarrow$ висновки $\rightarrow$ діяльність у відповідності з отриманим знанням. Саме ця ідея, як одна з провідних, була закладена в основу побудови Концепції Нової української школи, реалізації її принципів через тісний зв'язок знань, що отримуються, умінь та навичок, які набуваються, із життям; розвиток критичного мислення, самостійності та відповідальності. Так само алгоритмізовано працює кожен фахівець 3 дитиною, яка має особливі мовленнєві потреби: упродовж року кількаразово відбувається якісна перебудова 
освітнього маршруту з переходом на новий щабель розвитку 3 урахуванням мовленнєвих, розумових, емоційних надбань.

Карл Роджерс (Карл Ренс Роджерс) - американський психолог, засновник гуманістичної психології, розробник особистісно-зорієнтованої недирективної психотерапії, президент Американської психологічної асоціації, підкреслював, що якраз «Я-концепція», котра формується в процесі взаємодії людини із соціальним середовищем, $\epsilon$ інтегральним механізмом саморегуляції поведінки суб'єкта. На думку психолога, дитина є найвищою цінністю, яка має нагальну потребу в самоактуалізації та самореалізації своїх можливостей і саме поєднання навчання та розвитку стимулює пізнавальну активність. Молодші школярі з ТПМ мають труднощі у комунікації як з ровесниками, так і дорослими. Завдання будь-якого педагога, зокрема й у роботі з дітьми з особливими освітніми потребами, - стимулювати та ініціювати власну пізнавальну та мовленнєву активність дітей, а не нав'язувати їм директивно готові рішення.

Лев Виготський (Лев Семенович Виготський) - психолог зі світовим ім'ям, дослідник вищих психічних функцій, засновник «вершинної психології», нової психологічної теорії свідомості, вважав, що насправді навчання веде за собою розвиток. Коли учень може виконувати завдання без допомоги педагога, - це є його зоною актуального розвитку; коли молодший школяр потенційно спроможний опановувати певні знання, оволодівати уміннями та навичками за допомогою вчителя - це зона його найближчого розвитку. Саме розрив між цими обома зонами і формує, наповнює та стимулює освітній процес.

Леонід Занков (Леонід Володимирович Занков) - знаний психолог, автор системи розвивального навчання, фахівець у галузі спеціальної освіти, педагогічної психології, зокрема досліджень, дотичних до вивчення мнестичних процесів у дітей, взаємозв'язку слова та наочності, відмічав, що навчання має йти швидкими темпами та базуватися на теоретичних знаннях. Кожен предмет, що вивчається в умовах Нової української школи, має теоретичне підгрунтя. Навіть зважаючи на наявність у молодших школярів мовленнєвих розладів, недоречною в початковій школі $€$ повна заміна навчальної діяльності ігровою та надмірне розвантаження навчальних програм, що нівелює та в значній мірі гальмує навчальний процес загалом.

Пріоритетними завданнями сучасного освітньо-розвивального процесу i розроблення спрямованих на їх реалізацію освітніх 
стратегій $є$ кооперування команди фахівців, планування навчання, прогнозування та проміжне оцінювання очікуваних результатів, удосконалення розумових i мовленнєвих здібностей дітей із тяжкими порушеннями мовлення, концентрація на змісті засвоюваних теоретичних знань і отримуваних практичних навичок, акцент на впровадженні варіативних способів навчально-пізнавальної діяльності. Важливим у роботі з дітьми з ТПМ є використання таких метакогнітивних стратегій, коли за допомогою ефективного педагогічного впливу відбувається безпосереднє усвідомлення здобувачами початкової освіти своєї активності та самостійності в навчанні, підтримування позитивного відношення до загальноосвітньої та компенсаційної роботи, усвідомленого ставлення до рідної (української) та експериментального - до іноземної мов.

Отже, в основі навчально-виховної та компенсаційної роботи лежить розвиток мовленнєвої та пізнавальної діяльності у тісному зв'язку з активним спостереженням, залученням цілеспрямованої уваги та здатності до узагальнення мовних одиниць і явищ.

\section{2. Моделювання когнітивної компетенції молодших школярів з особливими мовленнєвими потребами}

Моделювання в освітньому процесі розглядається як метод пізнання і $є$ одним із засобів навчання (навчальні дії), якістю способу упорядкування змісту навчального матеріалу, що загалом сприяє всебічному (психофізичному, творчому, пізнавальному, мовленнєвому) розвитку учнів із тяжкими порушеннями мовлення. Використання навчальних моделей надає можливість молодшим школярам із ТПМ адекватно оцінювати графічно зафіксовану дійсність, керувати розвитком процесу та прогнозувати його наступне застосування. Саме за допомогою застосування моделей можна унаочнено простежити та відтворити суттєві властивості предметів і явищ, зв'язки досліджуваних процесів.

Процес моделювання являє собою структуровану цілеспрямовану діяльність, складові якої перебувають у тісному взаємозв'язку: а) аналіз матеріалу, що вивчається; б) перекодування текстового чи реального матеріалу на знаково-символічному рівні у модель; в) робота з моделлю і співвіднесення отриманих за її допомогою результатів 3 реальністю (В.Биков, В.Борисов, О.Куцевол, O. Мартинюк, В. Мелешко, Б. Набока, I. Підласий, Т. Рожнова, Ю. Тесля та ін.). 
Психолінгвістичне моделювання мовлення молодших школярів із ТПМ ставить за мету вивчення української мови як системи спочатку на інтелектуальному рівні, передбачаючи оперування зоровими опорами на позначення мовних одиниць (фонем, графем, лексем, морфем тощо), а згодом на рівні свідомості, користуючись уже уявними моделями. Психолінгвістичне моделювання відбувається у взаємозв'язку специфічних і неспецифічних пізнавальних процесів, емоційно-мотиваційної складової, рухової сфери, динамічномовленнєвого компоненту мовленнєвої діяльності, лексичної, морфологічної, граматичної, синтаксичної складових.

Наскрізним у психолінгвістичному моделюванні мовлення молодших школярів із ТПМ $\epsilon$ моделювання саме когнітивної компетенції. У 1862 р. в статті «Думка та мова» Олександр Потебня відомий вітчизняний філософ, мово- та літературознавець, вперше простежив зв'язок пізнавальних процесів 3 культурою мовної свідомості. У 2011 р. Олена Кубрякова - визначний лінгвіст, доктор філологічних наук, професор - в авторському збірнику «В пошуках сутності мови» репрезентувала повний аналіз когнітивної лінгвістики, що започаткувало нове поняття - «когнітивна компетенція».

У системі важливих характеристик якісного когнітивного мислення школяра на перший план виходять уміння творчо мислити та працювати 3 інформацією. Тому наявні труднощі у навчальній діяльності здобувачів початкової освіти із ТПМ допоможе скомпенсувати моделювання саме когнітивної компетенції. Когнітивна компетенція формує уміння володіти способами аналізу та рефлексії, ефективно планувати навчальну та вести пошуково-дослідницьку діяльність.

Когнітивні здібності проходять у своєму розвитку кілька етапів: 1 етап (базовий рівень) - накопичення інформації: запам'ятовування $\rightarrow$ зберігання $\rightarrow$ переведення 3 короткочасної пам'яті у довготривалу; 2 етап (середній рівень) - переробка інформації за допомогою логічних операцій та концептуальних систем (знаків, символів, таблиць тощо); 3 етап (високий рівень) - рівень творчого мислення (висування гіпотез $\rightarrow$ функціональний пошук $\rightarrow$ трансформація результатів дослідницької діяльності в освітній продукт), виконання широкого спектру універсальних навчальних дій, а саме: а) пізнавальних (формулювати проблему, моделювати, добирати інформацію, розуміти прочитане, структурувати знання, уміння будувати висловлювання, здійснювати самоаналіз діяльності); 
б) комунікативних (планувати навчальну співпрацю, ставити питання, виражати свої думки, узгоджувати свої дії з поведінкою партнера, вирішувати конфлікти); в) особистісних (самовизначення, смислоутворення); г) регулятивних (цілепокладання, планування, прогнозування, контроль, компенсація, оцінка) [4].

Формування в освітньому процесі різних видів модельних уявлень допомагає молодшим школярам із тяжкими порушеннями мовлення в ефективному виробленні універсальних навчальних дій. Використання символічної аналогії формує мнестичні прийоми роботи, таким чином полегшуючи і прискорюючи процеси запам'ятовування та засвоєння навчального матеріалу. Застосовуючи графічну аналогію, здобувачі початкової освіти з ТПМ вчаться бачити головне та систематизувати здобуті знання. Умовними замінниками, або елементами моделі, можуть виступати символи будь-якого характеру: геометричні фігури, символічні зображення предметів (умовні позначення, силуети, контури, піктограми), плани й умовні позначення, використовувані в них, графічні схеми фонетичного, морфологічного, синтаксичного аналізу.

Дидактичними завданнями наочного моделювання у роботі зі здобувачами початкової освіти з тяжкими порушеннями мовлення $\epsilon:$ a) ознайомлення із графічним способом репрезентування інформації (наприклад, на уроках української мови у другому класі можна використовувати алгоритми фонетичного розбору, де прямокутниками 3 написаними інструкціями виконання послідовності дій, від яких ідуть стрілочки взаємозв'язку, зазначено: 1) визначаю в слові голосні звуки (графічне позначення кружечком); 2) ділю слово на склади (вертикальна риска між складами); 3) ставлю наголос (графічна позначка наголосу); 4) позначаю приголосні звуки (одна горизонтальна рисочка на позначення твердих, дві - на позначення м'яких приголосних звуків); б) розвиток уміння дешифрувати модель (наявна звукова схема, підібрати до неї слово із запропонованих); в) формування навички самостійного моделювання (потрібно придумати слово відповідно до вказаної звукової схеми).

Моделювання когнітивної компетенції допомагає: а) активізувати пізнавальну та мовленнєву активність учнів із ТПМ; б) навчитися здійснювати пошукову та експериментальну діяльність під час навчання, зокрема вивчення української мови; в) цілеспрямовано розвивати мовлення учнів; г) збагачувати їхній активний словник; д) закріплювати навички словотворення; $е$ е) формувати й 
удосконалювати вміння використовувати в мовленні різні конструкції речень; є) описувати предмети, складати зв'язні розповіді.

Завдяки використанню моделювання когнітивної компетенції команда фахівців (учитель початкових класів, учитель-логопед i практичний психолог) допомагає дітям із ТПМ здобувати інформацію, проводити дослідження, порівнювати, складати чіткий внутрішній план розумових дій, мовленнєвого висловлювання, формулювати і озвучувати думки, робити висновки. Аналізуючи новий матеріал і графічно його позначаючи, здобувач початкової освіти з тяжкими порушеннями мовлення навчається самостійності, посидючості, зорово сприймає план своїх дій. У нього підвищується зацікавленість і відповідальність, формуються почуття задоволення від досягнутих результатів своєї діяльності, удосконалюються психічні процеси (пам'ять, увага, мислення), що позитивно позначається на ефективності логокомпенсаційної роботи.

Розвитку специфічних пізнавальних процесів сприятиме використання на уроці «Я досліджую світ» фотографій, розглядаючи які, першокласники визначають, що саме $є$ природними прототипами предметів, створених людьми (лапки крота з гострими кігтями ківш екскаватора, бабка - гелікоптер, кульбабка - парашут); на уроці «Безпека життєдіяльності» - загальнозрозумілих знаків (світлофор, наземний та підземний переходи тощо), які допомагають формувати життєву компетентність; на уроці математики - таблиць, за якими учні складають і розв'язують задачі, і блок-схем (типу

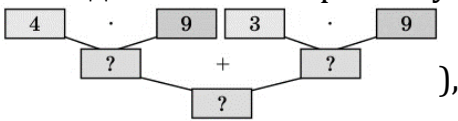

), за допомогою яких школярі розв'язують приклади.

Розвитку неспецифічних пізнавальних процесів на уроці «Літературне читання» слугуватиме використання ейдетичних образів, користуючись якими третьокласники вивчають напам'ять поетичні твори Тараса Шевченка (I досі сниться: - малюнок очей; під горою, - гора; між вербами - верби; та над водою - річка; біленька хаточка. - хатка-мазанка і т. п.). Розвитку емоційної складової на уроках «Основи здоров'я» сприяє програвання конфліктних, побутових, проблемно-пошукових життєвих ситуацій з використанням сюжетних картинок, іграшок бібабо, навчального обладнання, пісочниці тощо; рухової сфери - під час уроків із фізичної культури, на яких може здійснюватись унаочнення виконання 
статичних і динамічних вправ за допомогою піктограм і алгоритмів; образотворчого мистецтва, коли практична діяльність супроводжується графічним показом способу та послідовності виконання навчальних дій.

Кожен 3 напрямів логокомпесаційної роботи може також супроводжуватись наочним моделюванням: 1) у динамічно-мовленнєвому компоненті - використання фотографічних, реалістичних, контурних, силуетних, пунктирних зображень на позначення вправ артикуляційної, дихальної, голосової, пальчикової, мімічної гімнастики; 2) у фонетико-фонематичній складовій - моделювання слухового, зорового, рухового, графічного образу звука [5; 6], графічна алгоритмізація звуко-буквеного аналізу; 3) у лексичній складовій - основою для запам'ятовування нових лексем i збагачення словникового запасу можуть стати «картинні словнички», в яких учні із ТПМ малюють реальні зображення чи графічні схеми на позначення предметів, дій, явищ, ознак, т. ч. вивчаючи нові слова або уточнюючи їх значення; 4) у граматичній складовій шляхом виконання вправ на словотворення за допомогою використання наочних моделей активізується пошукова, експериментальна, аналітико-синтетична діяльність молодших школярів із ТПМ (наприклад, «квест-відкриття» етимології значення споріднених слів, написаних на кроні дерева, з метою знаходження спільного кореня; використання піктограм: сердечко - утворення лексем за допомогою зменшувально-пестливих суфіксів, ряду кружечків утворення множини іменників, прикметників чи дієслів); 5) у синтаксичній складовій: а) завдяки схематизації прийменникових моделей здобувачі початкової освіти з ТПМ чітко усвідомлюють значення прийменників, сприймають їх як окремі короткі слова, засвоюють правила їх роздільного написання з іншими словами; б) завдяки алгоритмізованій схемі школярі можуть складати описові розповіді (наприклад, про овочі та фрукти: знак питання найменування; кольорові плями - колір; набір геометричних фігур форма; великий і маленький будиночки - розмір; дотик: шматочок шпону - твердість, синтепону - м'якість, поліетилен - гладка поверхня, оксамитовий папір - шорсткість; лимон, цукерка, гострий перець - смак; дерево, кущ, кущик на землі, будиночок під землею місце зростання; каструля, сковорідка, духовка, тарілка, банка консервації, глечик - спосіб приготування, споживання); в) технологічні карти виготовлення поробок з пластиліну, паперу 
(конструювання, оригамі), малюнків стимулюють розвиток коментувального мовлення тощо.

Отже, учням початкової ланки з тяжкими порушеннями мовлення, яким притаманна швидка втомлюваність, психоемоційна виснажуваність і зниження інтересу до навчальної діяльності, саме моделювання когнітивної компетенції допомагає розвинути гнучкість і варіативність у сприйманні інформації, навчатися легко та невимушено, поступово переходити від унаочненого до умовносимволічного рівня засвоєння інформації, що в цілому дасть змогу підвищити ефективність компенсаційної та корекційно-розвивальної роботи.

\section{3. Формування когнітивно-мовленнєвої сфери молодших школярів із тяжкими порушеннями мовлення}

Розкриття сутності когнітивної компетенції, виокремлення рівнів розвитку когнітивних здібностей учнів із тяжкими порушеннями мовлення, спектру універсальних навчальних дій як складових метакогнітивних стратегій у диференційованому подоланні труднощів пізнавально-мовленнєвого розвитку здобувачів початкової освіти з ТПМ створили підгрунтя для розроблення методики логокомпенсаційної роботи, яка включає наступні розділи: 1) Підвищення нейродинамічних показників психічної діяльності, зокрема стимулювання концентрації та зосередженості, пробудження внутрішнього енергетичного потенціалу, нормалізація взаємодії збудження та гальмування в корі великого мозку, активізація міжнейрональних зв'язків. 2) Розвиток міжпівкульної взаємодії. 3) Формування різних видів ймовірного прогнозування, зокрема: a) невербальне прогнозування на рівні складів; б) невербальне прогнозування на рівні лексем; в) невербальне прогнозування на граматично-значеннєвому рівні; г) невербальне прогнозування на морфологічному рівні; г) невербальне прогнозування на синтаксичному рівні; д) невербальне рецептивне прогнозування; е) вербальне прогнозування на фонологічному рівні; $\epsilon$ ) вербальне прогнозування на рівні складів; ж) вербальне прогнозування на рівні лексем; 3) вербальне прогнозування на граматично-значеннєвому рівні; к) вербальне прогнозування на морфологічному рівні; л) вербальне прогнозування на синтаксичному рівні; м) вербальне прогнозування на рівні тексту; н) вербальне рецептивне прогнозування. 4. Розвиток психомовленнєвої діяльності, зокрема завдання, що передбачають аналіз умов проблемної ситуації, розв'язування логічних задач, 
розуміння причинно-наслідкових зв'язків, формулювання умовиводів, розвиток логічного мислення та комбінаторики. Завдання пропонуються нами за певною структурою: 1) обладнання (за потреби); 2) методичні рекомендації щодо проведення; 3) міні-мотивація до виконання у вигляді прозового, віршованого сюжету чи заклички; 4) інструкція; 5) мовленнєвий матеріал; 6) рівні допомоги.

\section{Підвищення нейродинамічних показників психічної діяльності}

Функціональна єдність нервової системи забезпечується завдяки тісному зв'язку між окремими елементами. Нервові волокна у центральній (головний і спинний мозок) та периферійній (черепні, спинномозкові нерви разом із комплексом нервових вузлів i нервових сплетінь) нервовій системі тісно прилягають одне до одного, виконуючи водночас різні функції та передаючи імпульси у різних напрямках до різних структур ЦНС. Процеси збудження i гальмування дуже динамічні і здатні поширюватись від місця свого виникнення на інші структури мозку. Чим інтенсивнішим $\epsilon$ нервовий процес, тим далі він поширюється і таким чином збільшується його вплив на суміжні ділянки мозку.

Для стимулювання концентрації та зосередженості, пробудження внутрішнього енергетичного потенціалу, нормалізації взаємодії збудження та гальмування в корі великого мозку стане в нагоді така вправа.

Чарівна вісімка. Методичні рекомендації щодо проведення: Учень (-иця) виставляє вперед праву руку з піднятим вгору великим пальцем. У напрямку вгору вліво починає повільно малювати велику горизонтальну вісімку, стежачи очима за пальцем. Теж саме виконує лівою рукою. Потім, склавши пальці в замок і піднявши вгору великі, так само розмашисто малює вісімки.

Активізації міжнейрональних зв'язків сприятимуть наступні вправи.

Пустотливий Морозець. Методичні рекомендації щодо проведення: Учень (-иця) інтенсивно тре долоню об долоню до появи відчуття тепла, потім одночасно обома руками розминає вуха.

Фізкультурник Гусак. Методичні рекомендації щодо проведення: Учень (-иця), спочатку уповільнено, а потім поступово пришвидшуючи темп, ритмічно, повторюючи за педагогом, а згодом самостійно, виконує вправу, чергуючи пози долонь. Обидві руки зігнуті в ліктях, розташовані вертикально: права рука - розкрита долоня перпендикулярна до передпліччя (гусак), ліва рука - долоня стиснута в кулак. Вправа може виконуватись у швидкому темпі під лічбу чи мовленнєвий супровід. 
Ось поїзд наш їде. Методичні рекомендації щодо проведення: Учень (-иця) робить швидкий вдих і на одному видиху багаторазово в швидкому темпі промовляє: $n-n-n$. Слідкувати, щоб грудна клітина не стискалась, активно працювали губи. Так само швидко зробивши вдих, на одному видиху багаторазово промовляти звукосполучення $n m \kappa$.

3 метою зняття психоемоційного напруження та релаксації доцільно використовувати дихальні вправи, міні-психоетюди.

На морському березі. Методичні рекомендації щодо проведення: Учень (-иця) має уявити себе на морському березі. Для цього буде доцільним використання аудіозапису шуму морських хвиль. Школяр, у вихідному положенні стоячи, напівзаплющивши очі, праву руку кладе на діафрагмальну ділянку, робить максимальний плавний повільний видих через рот. При необхідності вдиху глибоко із приємним розслабленим відчуттям вдихає носом. Продовжує дихання у природному, трохи уповільненому темпі.

Слідкувати, щоб діафрагма повільно рухалась, плечі не піднімались.

Основні показники завдання: вільне дихання без напруження.

Місточок через річечку. Методичні рекомендації щодо проведення: Вправу виконують два учні. Перший-виконавець з опущеними вздовж тулуба руками вільно спокійно дихає діафрагмою, другийконтролер кладе обидві руки йому на плечі, слідкуючи щоб вони не піднімались. Далі руки «контролера» переміщаються на рівень діафрагми (великий палець попереду, чотири інші - на спині) та слідкують за правильністю її руху. Потім ролі міняються.

Яскраві кульки повітряні. Методичні рекомендації щодо проведення: Учень (-иця) робить вдих на повні груди, потім повільно видихає, одночасно рахуючи вголос до восьми. Слідкувати, щоб видих був плавним, лічба не переривалась і звучала як одна фраза, без підвищення голосу. На наступних етапах тривалість видиху збільшувати.

Хазяйновитий вітерець. Методичні рекомендації щодо проведення: Учень (-иця) із зімкненими губами робить вдих носом на повні груди, потім повільно видихає зі звуком $\phi-\phi-\phi$. Слідкувати, щоб не надувались щоки, видихуваний струмінь виходив тільки через щілину між зубами та нижньою губою, щоб видих тривав при лічбі не менше ніж до 8-9. Можна змінювати звуки на видиху: $c-c-c, m-ш-ш$, $x-x-x$. Виконувати 3-4 рази підряд.

\section{Розвиток міжпівкульної взаємодії}

Міжпівкульна взаємодія лежить в основі функціонування усіх вищих психічних функцій, адже немає головної чи другорядної 
півкулі головного мозку. Чуттєва інформація з правої півкулі завдяки абстрактно-логічному аналізу у лівій півкулі перетворюється на певні образи, здійснюється порівняння предметів, визначення їх схожості чи відмінності, переробка мовленнєвої інформації. Наочно-чуттєві уявлення про предмети, створення асоціацій, метафоричне, емпіричне мислення, цілісність смислового змісту, опанування світу у його різноманітності забезпечується роботою правої півкулі. Завдяки діяльності лівої півкулі учень (-иця) здатен (-на) охарактеризувати предмет, граматично оформлювати власні висловлювання, застосовувати прийоми логічного, абстрактного мислення, встановлювати причинно-наслідкові зв'язки. Обидві півкулі головного мозку доповнюють діяльність одна одної, адже аналітико-синтетичні зв'язки при обробці будь-якої інформації, у кожному виді навчальної діяльності забезпечуються саме міжпівкульною взаємодією.

Для гармонізації роботи обох півкуль можна використати наступні вправи.

Млинці мої смачні й духмяні. Методичні рекомендації щодо проведення: Учень (-иця) кладе долоні на стіл, почергово перевертає долоні. Потім одну руку стискує в кулак, а інша залишається лежати на столі. Пози рук міняються. Спочатку вправа виконується в уповільненому, а потім у прискореному темпі.

Павучок-лісовичок. Методичні рекомендації щодо проведення: Учень (-иця) «плете павутину» - зігнутими в ліктях руками робить перехресні рухи до вух (права рука зверху), злегка стискаючи мочки вух вказівним і великим пальцями (права рука торкається лівого, ліва - правого вуха). Потім руки розпрямляються, школяр присідає. Підвівшись, робить перехресний рух, при цьому тепер ліва рука зверху. Вправа (перехрест, присідання, перехрест) виконується спочатку в уповільненому, а потім прискореному темпі. Варіантом виконання вправи, 3 метою прискорення темпу, може бути перехресне торкання до мочок вух і швидке переключення на плеск долонь перед грудьми (перехрест, плеск, перехрест).

Цирковий клоун. Методичні рекомендації щодо проведення: вправа виконується у швидкому темпі у кількох варіантах за ступнем ускладнення. Варіант 1. Учень (-иця) плескає руками перед грудьми, потім правою рукою торкається кінчика носа та правого вуха. Робить плеск. Теж саме виконує лівою рукою. Варіант 2. Школяр плескає руками перед грудьми, робить перехрест, торкається кінчика носа правою рукою і лівого вуха. Після сплеску змінює руки - торкається 
кінчика носа лівою рукою і правого вуха. Варіант 3. Учень (-иця) плескає руками перед грудьми. Обома руками торкається кінчика носа, робить перехрест, торкається протилежних вух.

Диво-робот. Методичні рекомендації щодо проведення: Учень (-иця) стоїть з витягнутими вперед руками, причому одна повернута долонею вгору, а інша - донизу. Варіант 1. Школяр починає марширувати, на кожен крок змінюючи положення долонь. Варіант 2. Зміна положення долонь відбувається через крок.

Цирковий канатоходець. Методичні рекомендації щодо проведення: Учень (-иця) стоїть з опущеними руками. Перед ним (нею) проведена пряма лінія - це «канат» під куполом цирку, по якому він (вона) має пройти як справжній канатоходець, тягнучи носок. Варіант 1. Школяр робить крок правою ногою, одночасно піднімаючи ліву руку в сторону. Робить крок лівою ногою - піднімає праву руку, а ліву при цьому опускає. Варіант 2. Учень (-иця) робить те ж саме, але рухається по «канату» у зворотному напрямку, спиною вперед.

\section{Формування різних видів ймовірного прогнозування}

Процеси сприймання та реалізації мовлення об'єднують передбачення наступних дій, або випереджувальне відображення, що проявляється по-різному, але відіграє надзвичайно важливу роль у набутті як загального життєвого досвіду, так і опануванні навчальною діяльністю, особливо школярами із тяжкими порушеннями мовлення. М. Жинкін акцентував увагу на тому, що у рецепції випереджувальне відображення проявляється в процесі ймовірного прогнозування, у продукції - випереджувального синтезу.

Як зазначає І. Зимня [7], механізм випереджувального синтезу є своєрідним регулятором специфіки побудови структурних компонентів мовних одиниць (склад, слово, фраза, речення), впливаючи на способи їх поєднання. М. Солобутіна вказує на те, що механізмом ймовірного прогнозування в мовленнєвій діяльності є передбачення майбутнього лексично, граматично та синтаксично правильно оформленого висловлювання, що грунтується на ймовірнісній структурі раніше набутого досвіду.

Слід зазначити, що ймовірне прогнозування має дворівневу структуру. На рівні змістових гіпотез здійснюється передбачення ходу розгортання комунікативного повідомлення та розвиток смислових зв'язків, а на рівні вербальних гіпотез реалізується передбачення їх конкретної вербалізації, а отже відбувається синхронне прогнозування змісту та вербальної форми.

Механізм ймовірного прогнозування $є$ досить складним. Для правильного виконання завдання учень (-иця) має зрозуміти смисл 
попередньої частини слова або речення, пропуску, проаналізувати фонетичні, морфологічні, лексичні, граматичні вимоги до пропущеної частини; за рахунок потенціалу довготривалої пам'яті актуалізувати мовні елементи, смислова сполучуваність яких з цим контекстом найбільш вірогідна; на рівні речення чи тексту граматично упорядкувати ці елементи і включити в парадигматичну схему. Ці операції передбачають наявність в учнів певного словникового запасу, сформованість лексичних умінь, пов'язаних 3 поєднанням мовних елементів, уміння розуміти простий текст; володіння основними граматичними структурами мови для побудови висловлювання. Пропонуємо завдання 3 розвитку невербального та вербального прогнозування на різних рівнях.

\section{Невербальне прогнозування на рівні складів}

Космічний мешканець. Обладнання: предметні зображення на позначення шкільного приладдя. Методичні рекомендації щодо проведення: Учень (-иця) за завданням педагога має показати «інопланетянину» ті зображення предметів, які починаються чи закінчуються на певний склад. Педагогом пропонуються не тільки ті зображення предметів, які відповідають поставленому завданню, а й конфліктні. Назви предметів можуть містити такі пари звуків, які викликають утруднення в мовленні школяра. Інструкція: Покажи, будь ласка, зображення тих предметів, назви яких закінчуються на склад... ТА (карта, парта), КА (ручка, указка, книжка, дошка, лінійка, гумка, стругачка).

\section{Невербальне прогнозування на рівні лексем}

Наталочка-школярочка. Обладнання: предметні зображення (рюкзак, книжка, фрукти, дзеркало). Методичні рекомендації щодо проведення: Учень (-иця) слухає початок словосполучення, яке написала Наталочка, та продовжує його, показуючи відповідне зображення. Інструкція: Покажи, будь ласка, зображення тих предметів, назви яких закінчують словосполучення: зручний... (рюкзак), цікава... (книжка), корисні... (фрукти), овальне... (дзеркало).

Слова-близнята. Обладнання: предметні зображення (шприц, їжак, ялинова гілка, голка для шиття; кулькова ручка, дверна ручка, ручка малюка; язик хворого, язички черевичків, заливний язик, язик базіки; гайковий ключ, дверний ключ, скрипковий ключ). Методичні рекомендації щодо проведення: Учень (-иця) має доповнити речення, розпочаті педагогом, словами-близнятами, показавши відповідні зображення. Інструкція: Покажи, будь ласка, зображення тих 
предметів, назви яких повинні закінчити речення. Зразки речень: 1) Голка: Щоб укол був безболісним, в шприці повинна бути гостра... (Голка) На пишній ялинці безліч духмяних колючих... (Голок) Їжачка захищають від хижаків колючі... (Голки) Щоб зашити порвані Дем'янком сині штанці, мама просилила синю нитку в... (Голку) 2) Ручка: Тепер всі школярі пишуть в зошитах кульковими... (Ручками) На вхідних дверях до класу Даринчин тато замінив... (Ручку) У малюка пухкенькі та чистенькі... (Ручки) 3) Язик (язичок): Лікар попросив хворого хлопчика показати... (Язик) У черевичках прикриває ногу зручний... (Язичок) Відмінною стравою для святкового столу є заливний... (Язик) Ліза-цокотушка була гострою на... (Язик) У церковному дзвоні не буде звуку без... (Язика) 4) Ключ: Тато ремонтував велосипед, а Петрик подавав йому гайковий... (Ключ) Олег вже школяр і має від квартирних дверей власний... (Ключ) На початку нотного стану часто стоїть скрипковий... (Ключ)

\section{Невербальне прогнозування на граматично-значеннєвому рівні}

Помічник кухаря. Обладнання: предметні зображення (кошик 3 овочами, тарілка борщу, відро з грибами, мішки цибулі). Методичні рекомендації щодо проведення: Учень (-иця), допомагаючи кухареві шкільної їдальні, продовжує розпочаті ним словосполучення, показуючи відповідні зображення: повний... (кошик), повна... (тарілка), повне... (відро), повні... (мішки). Інструкція: Покажи, будь ласка, зображення тих предметів, назви яких повинні закінчити словосполучення.

\section{Невербальне прогнозування на морфологічному рівні}

Mи у лісі. Обладнання: предметні зображення (вовчик, вовк, вовчище; ведмедик, ведмідь, ведмедище; грибок, гриб, грибище; дубок, дуб, дубище). Методичні рекомендації щодо проведення: Учень (-иця), «подорожуючи лісом», продовжує розпочаті педагогом речення, показуючи відповідні зображення. Зразки речень: Варіант 1. Від своїх батьків засвоїв навички здобувати здобич молодий... (Вовчик) Зграю водить за собою досвідчений... (Вовк) Взимку самотній голодний і злющий-презлющий бродить по лісу старий... (Вовчище) Варіант 2. Любить ласувати малиною молодий... (Ведмедик) В швидкій чистій річечці вправно ловить рибу... (Ведмідь) Навесні сонний і голодний виліз із барлогу величезний... (Ведмедище) Варіант 3. Свої перші листочки підставляє сонечку маленький... (Дубок) Щороку пригощає жолудями лісових мешканців... (Дуб) Своїм розлогим гіллям закриває лісову галявину 
від сонця могутній... (Дубище) Варіант 4. 3-під кленового листочка виглядає маленький... (Грибок) Після теплого дощу з'явився під сосною міцний красень... (Гриб) На кручі над рікою на одній нозі у величезному капелюсі стоїть справжній... (Грибище)

\section{Невербальне прогнозування на синтаксичному рівні}

Допоможемо Миколці. Обладнання: предметні картинки на позначення птахів (ластівка, шпак, лелека, папуга, сорока, дятел); транспорту (автобус, таксі, маршрутка, метро, фунікулер, катер), рослин (береза, сосна, каштан, бузок, комиш, соняшник). Методичні рекомендації щодо проведення: Учень (-иця) допомагає Миколці серед запропонованих вибрати потрібні зображення на позначення шкільного приладдя, перелітних птахів, транспорту, дерев, продовжуючи розпочаті педагогом речення шляхом показу відповідних картинок: Восени відлітають у вирій ... (Ластівки, шпаки, лелеки) Вулицями міста їздять...(Автобуси, таксі, маршрутки) У парку ростуть такі дерева... (Береза, сосна, каштан)

\section{Невербальне рецептивне прогнозування}

Ква-ква-розмова. Обладнання: картки-схеми слів. Методичні рекомендації щодо проведення: Учень (-иця), послухавши закличку, виконує завдання жабенят: в картки із написаним буквосполученням ква вписує в порожні клітинки слова, значення яких запропоновані педагогом в описових міні-загадках. Змістова частина завдання: Цей ква_ від спраги рятує. (Квас) Цей ква_ _. учень на дошці малює. (Квадрат) Ці _ _ _ква, ква _ _ _ _ на городі зростають. І разом у борщ потрапляють. (Морква, квасоля) Цей _. ква_ вас читати навчить. (Буквар) Цей _ _ква звук означає і мовчить. (Буква) Родина велика в ква____- цьому живе. (Квартира) А в цьому _ква ____ рибка-красуня пливе. (Акваріум)

\section{Вербальне прогнозування на бонологічному рівні}

Непосидючий вітер. Методичні рекомендації щодо проведення: Учень (-иця) виправляє слова, які «зіпсував» непосидючий вітер, здувши перший (останній) звук, називає слово цілком: ...овариш (Т), ...арета (К), ...ерерва (П); підручни... (К), кабіне... (Т), господа... (Р).

\section{Вербальне прогнозування на рівні складів}

«Хвостата мова». Методичні рекомендації щодо проведення: Учень (-иця) слухає розповідь педагога про хлопчика Степанка, який зміг навчити свого папугу Пантю кільком словам i, приїхавши до бабусі, був здивований, чому свійські тварини вимовляють тільки один склад. Школяр «вчить тварин вимовляти слова»: 1) баранця - зі складом бе: бе-гемот, бе-гонія, бе-кон, бе-рег, бе-реза, бе-тон, бе-сіда, 
бе-кас, бе-зодня, бе-рет, бе-резень; 2) козу - зі складом ме: ме-блі, ме-док, ме-даль, ме-дик, ме-дуза, ме-жа, ме-ліса, ме-льник, ме-моріал, ме-ню, ме-тал, ме-телик, ме-тро, ме-лодія, ме-ханік, ме-дунка, Ме-ланка; 3) корову - му: му-за, му-зика, му-ка, му-ліне, му-льтик, му-ляр, му-раха, му-ха, му-хомор, му-шля, му-шкет, му-зей; 4) курку ко: ко-ала, ко-бза, ко-била, ко-бра, ко-ник, ко-жух, ко-за, ко-зак, ко-кос, ко-лесо, ко-лібрі, , ко-ло, ко-лода, ко-лодязь, ко-лона, ко-лос, ко-ма, ко-лядка, ко-мар, ко-ра, ко-пиця, Ко-лобок, ко-лесо, ко-синка, ко-лія, ко-мандир, ко-маха, ко-лиска, ко-лисанка, ко-ліно, ко-валь, га-лушка, га-лявина, га-мак, га-чок, га-раж, га-лас; 6) курча - пі: пі-вень, пі-жама, пі-лот, пі-люля, пі-на, пі-нопласт, пі-петка, пі-ранья, пі-рат, пі-рога, пі-тон, пі-ца, пі-сок, пі-вонія, пі-на; 7) песика - гав: допома-гав, снови-гав, вибі-гав, натя-гав, оббі-гав, ля-гав, перемагав, спостері-гав, збері-гав; 8) кота - няв: під-няв, обій-няв, підга-няв, га-няв, від-няв, зай-няв, від-няв, підрів-няв, промі-няв, розборо-няв, най-няв, вирів-няв, припід-няв, ку-няв, ли-няв, перей-няв, зага-няв; 9) свинку - рох: го-рох, по-рох, скомо-рох.

\section{Вербальне прогнозування на рівні лексем}

Допоможемо Оленці. Методичні рекомендації щодо проведення: Учень (-иця), допомагаючи дівчинці Оленці влучно добирати слова, продовжує речення, розпочаті педагогом. Зразки речень: Варіант 1. Кожного дня нам листоноша приносить свіжу... (газету) Татусь щовечора читає в газеті свіжі... (новини) Бабуся завжди купляє в магазині свіжий... (хліб) Матуся слідкує за тим, щоб у Данилка завжди була свіжа... (сорочка) Варіант 2. На костюм три метри тканини... (йде) Школярі щоранку до школи... (йдуть) Ваш годинник точно... (йде)? Сьогодні цілісінький день сніг або дощ...(iде) Варіант 3. Тато подарував мамі... (золоту) обручку. У Петрикового дідуся... (золоті) руки. Олександр Петрович не тільки хороший лікар, а й людина, що має... (золоте) серце. У нашої бабусі... (золотий) характер.

\section{Вербальне прогнозування на граматично-значеннєвому рівні}

Рудик. Методичні рекомендації щодо проведення: Учень (-иця) уважно слухає оповідання, яке читає педагог і вставляє пропущені кінцівки слів. Завдання можна виконувати з опорою на слух, написаний текст, з використанням ілюстративного матеріалу та без нього або з руховими підказками. Змістова частина завдання: Петрика однокласники по-доброму називали Рудиком, бо в нього було руде волосся і симпатичні руді веснянки. Рудик дуже багато балакав і робив це швидко-швидко, так, що ніби ковтав закінчення 
слів. Ось послухай, що він сьогодні розповів: «Вчора я був у дельфінар... (ii) Там живуть дельфін... (u) Дельфін... (u) - морськ... (i) тварин... (u). Вони ма... (ють) св... (ою) мов... (y) і розумі... (ють) одне одн... (ого). Вон... (u) легк... (о) дресиру...(ються) і викону... (ють) різн ... (i) вправ... (u). Розумн... (i) тварин... (u) багато раз... (iв) рятув... (али) люд... (ей), які тону... (ли). Відвід...(айте) дельфінар... (ій) - там дуже-дуже цікав... (o)!»

\section{Вербальне прогнозування на морфологічному рівні}

Посадили ми дубочки. Методичні рекомендації щодо проведення: Учень (-иця) уважно слухає оповідання, яке читає педагог, і вставляє пропущені морфеми (префікси та суфікси). Завдання можна виконувати з опорою на слух, написаний текст, з використанням ілюстративного матеріалу та без нього, з руховими підказками. Змістова частина завдання: Дід... (усь) ...вів (по) своїх онуків Дмитр...а (ик) та Іван...а (к) на ...гу́лянку (про) до лісу. На галявині виросли молод...і (есеньк) ялин...и (очк), сос...и (онк), дуб...и (очк). А ось який велич...ий (езн) дуб...е (ищ)! А під ним - мал...ий (есеньк) молод...ий (есеньк) дуб... (очок). ...ховалось (за) серед лист...ів (очк) зажур...е (ен) малес...е (еньк) дерев...е (ц). Дід... (усь) ...радився (по) 3 Іван...ом (к) і Дмитр...ом (ик), і вони ....рішили (ви) ...копати (ви) дуб... (очок) і ...нести (від) його додому. Хлоп...и (чик) ...садили (по) дуб... (очок) у сад...у (к) і щоденно ...ливали (по) його. ...ростав (nid) дуб... (очок) разом із хлоп...ами (чик) на радість дід...еві $(y c)$, тат...i (к, ов) та мат...і (ус).

\section{Вербальне прогнозування на синтаксичному рівні}

На планеті Навпаки. Методичні рекомендації щодо проведення: Учень (-иця) слухає розповідь педагога про планету Навпаки, де трапляються різні дива, та пропонує виправити зміст речень. Зразки речень: Діти почали спускатись з гори на санчатах, бо... завтра вже піде сніг. Хлопчик Антон часто купався в річці, тому в ній... вода стала теплішою. Корову напоїли молоком, тому... вона віддала все сіно дітям. На деревах пожовтіло і почало опадати листя, бо... прийшла весна.

\section{Вербальне прогнозування на рівні тексту}

Бабусина казка. Методичні рекомендації щодо проведення: Учень (иця) слухає розповідь педагога про бабусю, яка вже старенька та пам'ятає лише початок (кінець) казки, пропонує замість бабусі розповісти казку повністю.

\section{Вербальне рецептивне прогнозування}

Серединки. Методичні рекомендації щодо проведення: Учень (-иця) читає слова (словосполучення, речення, текст), додаючи відсутню 
середину 3 опорою на ілюстративний матеріал чи без нього. Змістова частина завдання: со...ка (ба, ро, лом, сис, піл, ліст, роч, піл, лян, сон); по...ка (душ, друж, сил, лич, річ, лін, роб, сад, криш); ко...ка (син, лис, роб, сар, мір, рів, няч, ляд, сич, пич, пій)

Початки і хвости. Методичні рекомендації щодо проведення: Учень (-иця) читає слова (словосполучення, речення, текст), додаючи відсутню частину (початок, кінець) з опорою на ілюстративний матеріал чи без нього. Варіант 1. Зі спільною частиною: рак... (ета), ...рак (бат), .(т)рак...(тор), ...рак (2), ...рак (б). Варіант 2. 3 наявним початком: Роли... (ки), сире... (на), вогни... (ще), бере... (гu), приро... $(\partial a)$, окуля... (рu), абет (ка). Варіант 3.3 наявним кінцем: ...шут (пара), ...фон (теле), ...сипед (вело), ...шкар (шu), ...зета (га), ...дарунки (пода).

\section{Загальний розвиток психомовленнєвої діяльності}

\section{Аналіз умов проблемної ситуації}

Нова українська школа ставить перед здобувачами початкової освіти вимоги не лише у накопиченні окремих розрізнених знань, а насамперед у формуванні здатності застосовувати їх нестандартних умовах. Тому для молодших школярів із тяжкими порушеннями мовлення надзвичайно важливо не лише за допомогою педагога визначати пізнавальні задачі, виокремлювати їх складові, розуміти зміст, а й самостійно здійснювати необхідні розумові операції для досягнення потрібного результату, вийти за межі наочно розглянутих ознак предметів і явищ оточуючої дійсності, а й виокремлювати та встановлювати причиннонаслідкові зв'язки.

Важливими етапами (фазами) мисленнєвої діяльності (О. Лурія) є: а) попереднє орієнтування в умовах завдання (часто причиною труднощів $€$ нерозуміння запитання завдання чи недостатнє його розуміння); б) створення схеми (плану) його вирішення. Схема допомагає організувати та структурувати свою мисленнєву діяльність, цілеспрямовано виконувати запропоноване завдання; в) виділення способів вирішення, тобто відбір тих засвоєних знань і умінь, що необхідні для розв'язання певного завдання; г) порівняння результату з вихідним наміром чи умовою задачі 3 метою уникнення зайвих помилок просто через неуважність.

Пропонуємо кілька пізнавальних завдань для вироблення здатності аналізувати умови проблемної ситуації, виокремлювати значущі та несуттєві ознаки.

В яку сторону їде автобус? Обладнання: схематичне зображення автобуса. Методичні рекомендації щодо проведення: Учень (-иця) 
розглядає зображення автобуса та за завданням педагога визначає, у яку сторону їде автобус. Якщо школяр утруднюється з відповіддю, можна допомогти йому, поетапно запитуючи: «Що $\epsilon$ в цього автобуса? Так, колеса, вікна. А чого немає? Що ще має бути? Де ж двері? Отже, автобус їде...» Правильна відповідь: Ліворуч, бо ми не бачимо дверей, через які входять і виходять пасажири.

Малючок-домовичок. Методичні рекомендації щодо проведення: Учень (-иця) слухає історію-загадку педагога та пояснює чому головний герой робить саме так. Якщо школяр дає випадкові відповіді («тренується», «хоче схуднути», «відвідує друга на десятому поверсі»), йому потрібно пояснити, що його відповідь може бути і правильною, але він не враховує усіх даних історії, зокрема зріст головного героя. Текст історії-загадки: Домовичок живе на двадцятому поверсі. Щоранку, йдучи у своїх справах, він входить в ліфт, натискає кнопку i спускається на перший поверх. Повертаючись додому, він входить в ліфт, натискає кнопку i піднімається на десятий поверх, а далі йде пішки. Чому він не піднімається в ліфті на свій двадцятий поверх? Правильна відповідь: Домовичок маленького зросту, тому може дістати лише до десятої кнопки і змушений далі йти пішки.

Чарівна скринька. Обладнання: «чарівна скринька», предмети для відгадування, які вільно вміщаються в ній. Методичні рекомендації щодо проведення: Учень (-иця) повинен (-на) відгадати, який саме предмет сховано у чарівній скриньці, задаючи педагогові 10 уточнюючих питань, які б звучали таким чином, щоб на них можна було відповісти лише словами «так» чи «ні». Предмети для відгадування можуть стосуватись конкретної тематики (наприклад, шкільне приладдя) чи бути заздалегідь розглянуті школярем.

\section{Логічні задачі}

Логічне мислення лежить в основі розв'язання різного виду задач, 3 якими здобувачі початкової освіти зустрічаються в школі - рухових, оптико-просторових, математичних, граматичних. Елементарні прийоми логічного мислення найчастіше пов'язані з оперуванням одним судженням у прихованому вигляді. Наприклад, судження «Тополя вища за клен» дозволяє дізнатися, що «Клен нижчий за тополю». Далі логічні уміння зростають і пов'язані вже з оперуванням двома судженнями. Зокрема, на основі суджень «Тополя вища за клен. Клен вищий за горобину», можна зробити висновок, що горобина найнижче дерево. Удосконалення прийомів логічного мислення дає змогу не лише зробити певні умовиводи, робити висновки із 
запропонованих суджень, але й доводити правильність думки. Наприклад, судження «Тополя вища за клен. Клен нижчий за каштан. Клен вищий за горобину» дає змогу зробити висновок про таку градацію дерев за висотою: тополя, каштан, клен, горобина.

Завдяки розв'язанню логічних задач молодші школярі з тяжкими порушеннями мовлення легше можуть впоратись із завданнями 3 різних навчальних предметів, у них розвивається критичність, самостійність, кмітливість, здатність мислити послідовно, за законами логіки, поєднувати думки за певними правилами, засвоювати прості та складні види умовиводів, набуття навичок гнучкості думок, уміння оперувати стверджувальними та заперечувальними судженнями, удосконалюється швидкість реакції, вміння керувати власним психоемоційним станом у побутових i проблемних ситуаціях. Пропонуємо окремі зразки логічних задач.

Методичні рекомендації щодо проведення: Учень (-иця) має розв’язати логічні задачі та визначити правильну відповідь.

Варіанти простих задач:

- Ранок - вечір, зима - ?

а) холод; б) весна; в) сніг; г) літо; г) лижі; д) санчата.

- Софійка та Марійка пекли пиріжки: хто з капустою, а хто 3 м'ясом. У Марійки не було пиріжків із м'ясом. Хто пік з капустою?

а) Катруся; б) Софіка; в) Марійка; г) Світланка; г) Христинка; д) Поліна.

- В слові «БАК» переставили букви і вийшло слово «БКА». Аналогічна перестановка була в слові «ДУБ». Що вийшло?

а) БДУ; б) ДБУ; в) УДБ; г) БУД; г) УБД; д) ДУБ.

- Рік назад Дмитрик був старший за Олега. Хто старший зараз?

а) Максим: б) Олег; в) Іван; г) Дмитрик; г) Степан; д) Миколка.

Варіанти складних задач:

- На дошці написали слова кольоровими крейдочками:

КЛУМБА

ПІСНЯ

\section{ПАРКАН МОРОЗ}

Червоне слово лівіше від зеленого, чорне - нижче синього і правіше від зеленого. Якого кольору слово «КЛУМБА»?

а) червоний; б) синій; в) зелений; г) чорний; г) сірий; д) білий

- У слові «ЛИСТ» переставили букви і вийшло слово «СТЛИ». Така ж перестановка відбулась у слові «МОРЕ». Що вийшло?

а) ОРЕМ; б) ЕРОМ; в) РЕМО; г) ЕМРО; г') ЕМОР; д) ОМЕР.

- $\quad$ Були яблука та груші. Деякі фрукти поклали в миску, деякі в тарілку. Якихось було 2 кг, якихось - 3 кг, деякі фрукти були 
стиглими, деякі - нестиглими. Спочатку поклали чи то яблука, чи то в миску. Далі - чи то в миску, чи то ті фрукти, яких було 2 кг. Потім чи ті 2 кг, чи ті стиглі. Які фрукти були стиглими?

а) вишні; б) груші; в) сливи; г) яблука; г) абрикоси; д) черешні.

Розуміння причинно-наслідкових зв'язків, формулювання умовиводів

Мислення - це вища форма творчої активності людини. Саме завдяки мисленню ми здатні отримувати ті знання, що не можуть бути передані безпосередньо через органи чуттів.

Згідно з ученням 0. Лурії розуміння наукового тексту підручника вимагає від дитини: 1) виділення складових елементів тексту і найбільш інформативних його частин; 2) співставлення цих частин між собою (для цього вони зберігаються в оперативній пам'яті); 3) формулювання висновку за результатами співставлення; 4) складання короткої схеми, яка відображає в логічній формі основний зміст навчального матеріалу, що вивчається.

Хочеш вір, хочеш - не вір. Підготовча робота: 1. Експериментальна діяльність. Учень садить у горщик квасолинку та спостерігає за послідовністю її розвитку в структурі: квасолинка $\rightarrow$ росточок $\rightarrow$ стебло $\rightarrow$ квіточка $\rightarrow$ стручок. 2. Позакласне читання: «Як сорочка в полі виросла» К. Ушинського; «Казка про хліб» Н. Красоткіної. Методичні рекомендації щодо проведення: Учень (-иця), почувши три (чотири) слова, вибудовує з них логічний ланцюжок у відповідній послідовності. Закличка: Хочеш вір, хочеш - не вір, хочеш - сам (-а) перевір. Змістова частина завдання: Квіточка - вишня - компот; ікринка - пуголовок жабка; бавовна - нитки - тканина - сукня; глина - цегла - будинок; вівця - вовна - пряжа - светр; яйця - лялечка - гусінь - метелик.

Допоможемо Петрику. Методичні рекомендації щодо проведення: Учень (-иця) має допомогти Петрику продовжити речення, розпочаті педагогом, роблячи відповідні умовиводи. Змістова частина завдання: Поети пишуть вірші. Тарас Шевченко писав вірші, отже він... (nоет) Вітаміни - це речовини, потрібні людині для росту і розвитку. Отже, щоб рости і розвиватися, потрібні... (вітаміни) Екскурсовод водить гостей міста по історичних місцях. Микола Андрійович також знайомить гостей з історією міста, отже він... (екскурсовод) Дівчинка ходить в платтячку із бантиками в косичках. Ця дитина - в платтячку і з бантиками, отже це... (дівчинка) Все тіло птаха покрито пір'ям. Ця істота також покрита пір'ям, отже це... (nтах) Різьбяр по дереву вирізує різні предмети і візерунки. Борис Іванович також вміє все вирізувати з дерева, отже він... (різьбяр) 
Взимку тріщать морози, все покрито снігом. Вже цілий місяць морозно, кругом лежить сніг, отже зараз... (зима)

Верткий Максимко. Методичні рекомендації щодо проведення: Учень (-иця) допомагає верткому неуважному Максимкові встановити логічну послідовність подій в тексті, переставивши речення в потрібному порядку. Запропоновані речення можна написати на окремих картках чи одне під одним. Мотиваційна складова: Вчитель повідомив учнів, що зараз вони писатимуть переказ. Прочитав текст і всі учні почали старанно працювати, тільки Максим вертівся за партою. Тому у нього ось що вийшло... Змістова частина завдання: Шпачок весело заспівав (8) Андрійко відняв у кота пташку (3) Андрійко випустив пташку у вікно (7) Крило швидко загоїлось (6) До кімнати забіг кіт Чудик (1) Шпак жив у Андрійковій кімнаті (5) В зубах він тримав шпака (2) У неї було поранене крило (4)

\section{Розвиток логічного мислення та комбінаторики}

В умовах Нової української школи зросла вага загальнологічних мисленнєвих умінь учнів, адже під час засвоєння шкільних знань рівень мислення потребує більшого ступеня абстракції, вищих форм узагальнення, вміння відволікатися від несуттєвих, другорядних ознак і виділяти найголовніше, аналізувати, порівнювати інформацію. Особливо важливими $\epsilon$ вербальний супровід виконуваних мисленнєвих дій, здатність розповісти про хід власних думок, довести правильність чи хибність запропонованих міркувань. Для молодших школярів із тяжкими порушеннями мовлення саме опора на власний емпіричний досвід дає змогу активізувати розвиток вербальних форм логічного мислення.

Причина, явище $і$ наслідок. Методичні рекомендації щодо проведення: Учень (-иця) слухає розповідь учителя, намагаючись виокремити причину, явище та наслідок. Після цього, почувши фрази, запропоновані вчителем, озвучує можливий наслідок подій. Мотиваційна складова: Вчитель дав учням домашнє завдання написати твір на тему «Причина, явище і наслідок». Він детально розповів, як це зробити, але Ігор не слухав, тому нічого не запам'ятав. Хлопчик прийшов додому, розгорнув зошит та не зміг нічого пригадати з того, про що розповідав учитель. Так і пішов назавтра до школи $з$ невиконаним завданням. Змістова складова: Випадково насипати в чай солі - ... (чай солоний) Вийти на тонкий лід - ... (можна провалитись) Дражнити незнайомого пса - ... (може вкусити) Гуляти з м'ячем біля дороги - ... (попадеш під машину) Змішати білу та червону фарби - ... (буде рожева) Забути виконати домашнє завдання - ... (буде соромно) Посадити пташеня в клітку - ... (може загинути) 
Леся-помічниця. Методичні рекомендації щодо проведення: Учень (-иця) слухає розповідь педагога про Лесю-помічницю, яку мама навчала всьому, бо хотіла щоб донечка якомога більше знала і уміла. Школяр має запропонувати варіант дії у відповідь на кожну фразу-запитання педагога: «Як можна дізнатися, чи...?» Змістова складова: Чи готова запіканка? - ... (проколоти ї̈ паличкою) Чи підходять за розміром черевики? - ... (приміряти) Чи свіжа ця риба? - ... (подивись на зябра) Чи цікава книжка? - ... (прислухатись до порад) Чи варто йти до школи в неділю? - ... (ні, бо ще вихідний) 3 чим пиріжок? - ... (відкусити шматочок)

Добре - погано. Методичні рекомендації щодо проведення: Учень (-иця) слухає розповідь педагога про пригоди Робінзона Крузо, розглядає порівняльну таблицю (див. табл. 1) та знаходить позитивне та негативне в одних і тих самих подіях на безлюдному острові. Мотиваційна складова: Коли Робінзон Крузо потрапив на безлюдний острів, він не злякався небезпек, які очікували на нього. Чоловік проявляв наполегливість, силу волі, працелюбність i оптимізм, які допомогли йому вижити. Для цього він в кожній негативній ситуації став знаходити щось позитивне.

Таблиця 1

Міркування Робінзона про негативне та позитивне в його житті

\begin{tabular}{|l|l|}
\hline \multicolumn{1}{|c|}{ Погано } & \multicolumn{1}{c|}{ Добре } \\
\hline $\begin{array}{l}\text { Я потрапив на безлюдний острів } \\
\text { i в мене немає жодної надії на } \\
\text { порятунок }\end{array}$ & $\begin{array}{l}\text { Але я залишився живим, хоч міг } \\
\text { потонути, як всі інші члени команди }\end{array}$ \\
\hline $\begin{array}{l}\text { Я віддалений від інших людей, я } \\
\text { тут зовсім самотній }\end{array}$ & $\begin{array}{l}\text { Проте я не помер з голоду і не } \\
\text { загинув у цій пустелі }\end{array}$ \\
\hline $\begin{array}{l}\text { Я не можу захистити себе, якщо } \\
\text { на мене нападуть злі люди чи } \\
\text { хижі звірі }\end{array}$ & $\begin{array}{l}\text { Але тут немає ані людей, ані звірів, і } \\
\text { я можу вважати себе щасливим, що } \\
\text { мене не викинуло на берег Африки, } \\
\text { де стільки жахливих хижаків }\end{array}$ \\
\hline $\begin{array}{l}\text { Мені ні з ким перемовитись й } \\
\text { словом, нікому підбадьорити та } \\
\text { втішити мене }\end{array}$ & $\begin{array}{l}\text { Але я встиг зробити запаси, } \\
\text { необхідні для життя, і забезпечити } \\
\text { собі прожиток на тривалий час }\end{array}$ \\
\hline
\end{tabular}

Змістова складова: 1) Листопад: негативне - дерева стануть голими, робиться сумно; позитивне - можна милуватись незвичним танцем падолисту, листя вберігає землю від морозу; 2) Дощ: негативне - можна намокнути і застудитись, поєднуючись із землею, стає брудом; позитивне - напуває рослини, зволожує землю, змиває пил з предметів живої та неживої природи; 3) Сонце: негативне - можна отримати 
тепловий удар, опік, висушує водойми, гинуть рослини; позитивне - дає світло, тепло, сприяє росту рослин, можна засмагати, заряджає сонячні батареї.

\section{Подолання стереотипї̈ мислення}

Формування стереотипії під час шкільного навчання відбувається постійно - це і виконання вправ за певним алгоритмом, і розв'язання задач за схемою, і виконання поробок чи малюнків згідно з технологічною картою, і переказ тексту за певним планом тощо. Водночас розвиток гнучкості і критичності мислення, здатності швидкого пошуку нестандартних рішень має надзвичайно важливе значення не лише для результативної навчальної діяльності, а й життя загалом.

Талановиті пальчики. Методичні рекомендації щодо проведення: Учень (-иця) слухає розповідь педагога, що завдяки фантазії будьякий, здавалось би вже непотрібний, предмет можна перетворити в інший - цікавий і корисний. Школяр фантазує, що можна виготовити 3 того чи іншого вже непотрібного предмета. Змістова складова: Картонний пакет 3-під молока - годівничка, скарбничка, підставка під ручки, іграшки, ваза. Футлярчик з кіндер-сюрпризу - веселий чоловічок, ялинкові прикраси, маракас, брязкальце, квіти, звірята, бджілка, масажер, футлярчик, брелок для ключів. Рукавички - гра «Сім'я», атрибути для ігор-драматизацій, тіньового театру, птахи, звірята, м'які іграшки. Коробочки з-під «Тік-таку» - футлярчики для зберігання робочої частини зубної щітки, навушників, дрібного канцелярського приладдя (скріпки, кнопки), бісеру, спецій, стругачки для олівців.

\section{Розвиток мнестичних функцій}

Під час шкільного навчання розвиток пам'яті відбувається шляхом від мимовільного запам'ятовування почутої інформації до довільного запам'ятовування, тісно пов'язаного 3 мисленням, основаним на осмисленні засвоюваного матеріалу. Перед здобувачами початкової освіти постає необхідність довільного запам'ятовування. Спочатку домінує механічне запам'ятовування, яке поступово переходить до смислового. Згодом смислова пам'ять набуває опосередкованого логічного характеру.

у молодших школярів із тяжкими порушеннями мовлення найбільше страждає слухомовленнєва пам'ять, тому, при роботі 3 ними, доцільно спиратися на зорову пам'ять, підкріплюючи слуховий стимул картинкою чи зоровим образом, на мислення (запам'ятовування за допомогою логічних зв'язків), оптико-просторові відношення (структуруючи навчальний матеріал у просторі).

Розвиток психомовленнєвої діяльності учнів початкової ланки тісно пов'язаний із грою, адже емоційна залученість до виконання завдання, використання гумору забезпечує природне зростання 
рівня працездатності, запам'ятовування, сприяє появі мотивації до виконання певної діяльності, а отже - підвищенню ефективності роботи школяра.

Детектив. Методичні рекомендації щодо проведення: Учень (-иця) слухає розповідь педагога про злодія i, 3 метою кращого запам'ятовування, відповідно до змісту на аркуші паперу робить схематичні замальовки. Потім, користуючись власними символамипідказками, переказує оповідання. Змістова складова: Серед темної ночі один невезучий злодій забрався до власної квартири і викрав 1 ноутбук, 8 черевиків, 3 сорочки, 6 ложечок і 2 каструлі. Наступного дня все це він продав. Повернувшись додому, невезучий злодій побачив, що його квартиру обікрали. Не розібравшись у чому справа, він написав заяву у поліцію.

Кмітливі сестрички. Методичні рекомендації щодо проведення: Учень (-иця) слухає двослівне речення, промовлене педагогом, i, щоразу повторюючи його з самого початку, додає по одному слову. Мотиваційна складова: В школі додому дали завдання придумати речення «ланцюжком» - щоразу додаючи по одному слову. Двом сестричкам Надійці та Софійці не хотілось виконувати завдання, адже вони дуже люблять малювати і їм хотілось малювати і тепер. Дівчатка порадились і вирішили поєднати малювання з виконанням завдання та робити це почергово. Змістова складова: Софійка: Ми малюємо. Надійка: Ми малюємо в альбомах. Софійка: Ми малюємо в альбомах після уроків. Надійка: Ми малюємо в альбомах після уроків в школі. Софійка: Ми малюємо в альбомах після уроків в школі олівцями. Надійка: Ми малюємо в альбомах після уроків в школі олівцями та фарбами. Софійка: Ми малюємо в альбомах після уроків в школі олівцями та фарбами тварин. Надійка: Ми малюємо в альбомах після уроків в школі олівцями та фарбами тварин Африки.

\section{Висновки}

За результатами апробації логопсиходіагностичної методики вивчення пізнавального розвитку учнів початкової ланки були визначені механізми специфічних мовленнєвих розладів, що дало змогу розробити психолінгвістичні дидактичні технології подолання мовленнєвих порушень у молодших школярів з ТПМ.

Нами було запроваджено поняття «метакогнітивні стратегії в освіті дітей з особливими мовленнєвими потребами». Метакогнітивна стратегія $\epsilon$ непрямою. В ній освіта трактується як всебічний розвиток особистості, коли за допомогою ефективного педагогічного впливу відбувається безпосереднє усвідомлення молодшими школярами з тяжкими порушеннями мовлення рівня 
своєї активності та самостійності в навчанні, підтримання позитивного та відповідального відношення до освітнього процесу і компенсаційної роботи, усвідомленого ставлення до рідної (української) та експериментального - до іноземної мов.

Нами проаналізовано види та складові моделювання в освітньому процесі. Це дало змогу показати як з теоретичних, так і практичних позицій, що психолінгвістичне моделювання мовлення молодших школярів із ТПМ передбачає вивчення української мови як системи спочатку на інтелектуальному рівні, здійснюючи оперування зоровими опорами на позначення мовних одиниць (фонем, графем, лексем, морфем тощо), а згодом на рівні свідомості, користуючись уже уявними моделями. Було доведено: психолінгвістичне моделювання відбувається у взаємозв'язку специфічних і неспецифічних пізнавальних процесів, емоційно-мотиваційної складової, рухової сфери, динамічно-мовленнєвого компоненту мовленнєвої діяльності, фонетико-фонематичної, лексичної, морфологічної, граматичної та синтаксичної складових.

Правильно продумані та ефективно впроваджені спеціальна навчально-виховна та корекційно-розвиткова складові дадуть змогу учням 3 особливими освітніми потребами, зокрема 3 тяжкими порушеннями мовлення, на засадах рівності та доступності, взаємної довіри, толерантності і взаємоповаги повноцінно здобувати освіту у Новій українській школі.

\section{Література}

1. Концепція Нової української школи URL: http://mon.gov.ua/ activity/education/zagalna-serednya/ua-sch-2016/konczepcziya.html

2. Рібцун, Ю.В. (2020). Учні початкових класів із тяжкими порушеннями мовлення: навчання та розвиток. Львів : Світ.

3. Гуманітарна політика Української держави в новітній період : моногр. / за ред. С. І. Здіорука (2010). К. : НІСД.

4. Щедровицкий, Г. М. (2005). Мышление - Понимание Рефлексия. М. : Наследие ММК.

5. Рібцун, Ю. В. (2020). У країні Веселкових звуків. Альбом учителя-логопеда. Ч. 2. Х. : Видавнича група «Основа».

6. Рібцун, Ю.В. (2019). Я учуся розмовляти : навч.-метод. комплект : логопедичний альбом з розвитку мовлення дошкільників 3-6 років. Київ : Генеза.

7. Зимняя, И. А. (2001). Лингвопсихология речевой деятельности. Воронеж : НПО «МОДЭК». 